\title{
FORMA DE PAGO \\ Y PROTECCIÓN DEL DERECHO \\ A LA COMPENSACIÓN ECONÓMICA POR DIVORCIO O NULIDAD*
}

\author{
Álvaro Vidal Olivares"**
}

\section{RESUMEN}

La compensación económica constituye un derecho y correlativamente una obligación de origen legal que, una vez establecida, se somete al Derecho Común, propio de las obligaciones. Su titular tiene un crédito desprovisto de protección como tal. Quien debe dotar de protección al crédito de compensación es el juez, en él, el legislador radicó la tarea. El marco legal sobre su forma de pago apunta hacia esa dirección y le fija restricciones de observancia necesaria, que también los cónyuges deben acatar en sus acuerdos.

Palabras claves: Divorcio, compensación económica, pago.

\begin{abstract}
Financial compensation constitutes a right and subsequently a legal originated obligation that, once established, is subjected to Common Law, typical of obligations. Its holder has a claim deprived of protection as such. The judge is the one who must provide of protection the compensation credit, because the legislator settled this task on him. The legal frame of its payment form aims towrds that direction and fixes restrictions of compulsory observance, which also the spouses must respect in their agreements.
\end{abstract}

Key words: divorce, financial compensation, payment.

* El presente trabajo se ha elaborado en el marco de la ejecución del proyecto FONDECYT No 1070731, cuyo investigador responsable es el profesor de Derecho Civil de la Universidad Diego Portales, Carlos Pizarro Wilson.

** Doctor en Derecho. Profesor de Derecho Civil, Pontificia Universidad Católica de Valparaíso. Correo electrónico: alvaro.vidal@ucv.cl. Artículo recibido el 27 de marzo de 2009 y aceptado el 15 de mayo de 2009. 


\section{Preámbulo}

Hasta ahora, la doctrina ha estudiado de la compensación económica su calificación jurídica y fundamento, el supuesto que la hace procedente y sus condiciones. La mirada se ha fijado en la institución misma, no así en los problemas que plantea y planteará en el terreno práctico, como su cuantificación y forma de pago. En este trabajo me ocuparé de este último tema y de la protección del derecho a la compensación económica ${ }^{1}$.

Establecida y fijada su cuantía, sea por acuerdo o decisión judicial, ella se traduce en un derecho personal cuya fuente es la ley, con independencia de que sea un efecto patrimonial del matrimonio, como lo reconoce expresamente el propio artículo 60 de la LMC. Es un derecho personal del cual es titular el cónyuge que se halla en el supuesto del artículo 61, que lo tuvo por reconocido; y que desde que nace, se somete al Derecho común del libro IV del Código Civil sobre obligaciones y contratos. Es un derecho que no goza de preferencia de pago, como los que tienen la calidad de privilegiados.

El legislador no protege directamente al derecho de compensación, sino que asigna al juez de familia la tarea de dotarlo de una protección, según sean las particulares circunstancias del caso $^{2}$, y que se concreta en

${ }^{1}$ Hasta ahora, salvo un reciente trabajo, del profesor Carlos Pizarro Wilson, que se ocupa de la aplicación jurisprudencial de los artículos 65 y 66 de la LMC sobre el pago de la compensación económica, la doctrina ha tratado de manera general y más bien tangencial tal tópico. Véase Carlos Pizarro Wilson, "El pago de la compensación económica en la jurisprudencia nacional”, en Compensación económica por divorcio o nulidad, Santiago, Ediciones Universidad Diego Portales, Escuela de Derecho, Cuadernos de Análisis Jurídicos, 2009, vol. v. Así, Carmen Domínguez Hidalgo, "Compensación económica en la nueva ley de matrimonio civil", charla efectuada el 13 de octubre de 2005, en Revista del Abogado, No 35, serie Conferencias, Santiago, noviembre 2005, p. 25; Maricruz Gómez DE LA TORRe, Compensación económica en la nueva ley de matrimonio civil, Santiago, Colegio de Abogados de Chile, folleto, 2005, p. 16; Carlos Pizarro Wilson, "La compensación económica en la nueva Ley de Matrimonio Civil", en Revista de Chilena de Derecho Privado, No 3, Santiago, diciembre 2004, p. 99-101 y Álvaro Vidal Olivares, "La compensación por menoscabo económico en la Ley de Matrimonio Civil", en Álvaro Vidal Olivares (coord.), El nuevo Derecho chileno del Matrimonio (Ley N 19.947 de 2004), Santiago, Editorial Jurídica de Chile, 2006, pp. 282-284.

${ }^{2}$ Cobran especial relevancia las circunstancias del artículo 62 de la LMC. Si bien ellas tienen asignada la función de determinar la existencia del menoscabo y la cuantía de la compensación, a mi juicio, también debieran orientar la labor judicial en el sentido de que la modalidad de pago que se establezca encuentre su justificación en ellas. Así, por ejemplo, si resalta la precaria o inexistente situación previsional del cónyuge demandante, el juez debiere decretar como forma de pago, no exclusiva necesariamente, el traspaso de los fondos de capitalización individual dentro de los limites de la ley $\mathrm{N}^{\circ} 20.255$; o si la edad y el estado lo justifica, decretará la constitución de un derecho real sobre el inmueble que sirve de residencia al cónyuge acreedor o, bien, su dación en pago. La misma situación 
la forma de pago de la obligación correlativa de compensación, que debe ajustarse al marco legal de los artículos 65 y 66 de la LMC. La ley fija las modalidades de entrega que puede adoptar y el juez imperativamente debe inclinarse por alguna de ellas en su sentencia. Ahora bien, lo que constituye una norma para el juez, debe actuar como límite de la autonomía de la voluntad, por ser este marco legal indisponible tanto para el juez como para las partes. La hipótesis que se demostrará en este trabajo es que el juez debe regular la forma de la asignación ajustándose al marco de la LMC desde que ellas representan un mínimo de protección para el cónyuge acreedor y de su interés en cuanto cónyuge.

Empero, en la jurisprudencia se observa que los jueces de familia ignoran el citado marco legal y al condenar al desembolso de una compensación, por regla general, la dividen en cuotas sin fijar seguridad para su solución, lo que torna más grave si se considera el elevado número de cuotas en que dividen el monto, en muchos casos coincidiendo con la pensión de alimentos que hasta el divorcio pagaba el cónyuge deudor. Y, como si fuera poco, el juez tampoco -dado que no lo pide el demandado favorecido por el fraccionamiento- somete a la compensación a lo que prescribe el artículo 66 de la LMC que considera las cuotas alimentos para efectos de su incumplimiento ${ }^{3}$. A lo anterior se añade que cuando las partes solicitan la aprobación judicial de un acuerdo de compensación, el juez no presta mayor atención al pacto sobre la forma de pago, pese el carácter indisponible de los preceptos de los artículos 65 y 66 de la LMC, limitándose a aprobarlo sin más. Estrictamente, si el juez llega a constatar que las partes sobrepasan el límite legal representado por los citados preceptos, debiese corregir el acuerdo según el artículo 31 de la LMC, como si se tratase de uno regulador de separación judicial o de divorcio (artículos 27 y 54 de la LMC) ${ }^{4}$.

patrimonial determinará si se aplica o no la norma del artículo 66, asimilando las cuotas en que se divide la compensación a los alimentos debidos por ley.

${ }^{3}$ Para un estudio crítico sobre la forma de pago de la compensación económica en la jurisprudencia, véase PizARRo Wilson (n. 1). El autor analiza cincuenta y dos causas entre los años 2006 y 2007 escogidas en un universo de doscientas ochenta y seis sentencias de divorcio en que intervino la Corte Suprema en el año 2007 y se apoya en el análisis estadístico realizado por la socióloga María José Azocar, académica de la Universidad Diego Portales, en el marco del proyecto de investigación FONDECYT N 1070731 del que el profesor Carlos Pizarro Wilson es investigador responsable y el suscrito coinvestigador.

${ }^{4} \mathrm{Si}$ bien el artículo 31 refiere al acuerdo regulador de la separación judicial solicitada de común acuerdo, confiriendo facultades exorbitantes al juez tanto para modificar como completar el acuerdo, no hay duda que ella se extiende a los casos de divorcio solicitado de común acuerdo. También se cita como argumento a favor el reconocer la facultad del juez para controlar y corregir el acuerdo, el principio de actuación de oficio que rige 
Hoy, esta actitud jurisprudencial pasa inadvertida y se justifica en la necesidad de conceder compensaciones económicas, pese de la insuficiencia de facultades económicas del cónyuge deudor para satisfacerla y la incapacidad de ofrecer seguridades suficientes para el pago ${ }^{5}$; sin embargo, es previsible que durante el período de solución de la deuda sobrevengan incumplimientos y los acreedores afectados, desprovistos de toda seguridad, se vean forzados a demandar ejecutivamente y como cualquier otro acreedor quirografario, quedando expuesto a las vicisitudes que pueda experimentar el patrimonio del deudor incumplidor, patrimonio que muy probablemente en ese momento estará vacío. Esta práctica judicial, casi generalizada, pone en serio peligro la consecución de la finalidad perseguida por la compensación económica y, consiguientemente, el respeto de uno de los principios rectores del nuevo Derecho Matrimonial, el de la protección del interés del cónyuge más débil del artículo 3 de la LMC, a quien su artículo 61 le reconoce el derecho a la compensación por el menoscabo que le causará el divorcio o nulidad.

La finalidad perseguida por la LMC, así fluye de la historia de su establecimiento, es que el conflicto entre los cónyuges en lo patrimonial se resuelva de una sola vez, o en el menor tiempo posible, lo que se ve reflejado en el marco legal sobre la forma de entrega que pasa desde la consignación de un monto o de una pensión compensatoria por un plazo máximo de cinco años (artículo 38 de la indicación del Presidente de la República) a una suma única que puede dividirse en cuotas siempre que el deudor ofrezca seguridades para el cumplimiento suficientes (actual artículo 65 de la LMC) ${ }^{6}$.

en derecho procesal de la familia (art. 9 y 13, ley $\mathrm{N}^{\circ}$ 19.698). Así lo entiende Carmen Domínguez Hidalgo, "El convenio regulador y la compensación económica: una visión de conjunto", en Anastasía Assimakópulos Figueroa y Hernán Corral Talciani (eds.), Matrimonio civil y divorcio, Análisis crítico y criterios para la aplicación de la Ley $N^{\circ}$ 19.947, de 2004, Santiago, Universidad de Los Andes, 2005, p. 100 y Corral Talciani, Hernán, "La compensación económica en el Divorcio y la Nulidad Matrimonial”, en Revista Chilena de Derecho, vol. 34, N ${ }^{\circ}$, Santiago, 2007, p. 37.

${ }^{5}$ Con relación a este punto cabe precisar que la LMC no exige el otorgamiento de garantías reales o personales, sino de seguridades para el pago, noción más extensa y que concede al juez un margen más amplio de actuación y, además, que ella prevé explícitamente, en su artículo 66, el caso de la insuficiencia de bienes del deudor para pagar la compensación y la imposibilidad de dar seguridades suficientes. Pareciera que los jueces ignorasen el alcance del marco legal de la forma de pago, justificándose plenamente, de este modo, el presente trabajo.

${ }^{6}$ A lo anterior se suma que durante la discusión parlamentaria el ex ministro José Antonio Gómez sostiene que la compensación económica tiene la gran ventaja de poner tempranemente fin a la discusión económica, evitando perpetuar el conflicto familiar, como ocurre con los alimentos debidos por ley, en que las solicitudes de rebaja o aumento son fuente de constantes enfrentamientos, eternizando las odiosidades. Vidal Olivares (n. 1), pp. 5 y $236-237$. 
Se quiere evitar la perpetuación del conflicto entre los cónyuges o que con ocasión del pago de la compensación surjan otros que pudieran afectar el interés de los hijos comunes. Tal objetivo se alcanza idealmente mediante la entrega de una suma alzada, única, global e inmodificable, pagadera de contado o, cuando mucho, dividida en un reducido número de cuotas. No obstante, ésta es una aspiración del legislador que choca frontalmente con la realidad socioeconómica de nuestro país, y que hoy hace que la regla sea la parcelación en cuotas ${ }^{7}$ o la constitución de derechos reales, aunque en forma más aislada ${ }^{8}$. Siendo así, cobra especial relevancia tal finalidad a la hora de analizar el marco legal sobre la forma de extinción de esta obligación. Si bien la regla en la práctica está representada por el desembolso en cuotas, éstas debieren ser de número reducido e ir acompañadas con seguridades de cumplimiento. Así lo dispone el artículo 65 de la LMC. En el caso de un derecho real sobre un bien de propiedad del cónyuge deudor, su constitución debiere ser valorada, fijando el tiempo que se mantendrá vigente. La división en un número ilimitado o extenso de cuotas, incluso, con seguridades de pago, o la constitución de derechos reales con el carácter de vitalicio, frustran abiertamente la mencionada finalidad ${ }^{9}$.

\footnotetext{
${ }^{7}$ Así lo anticipaban Domínguez Hidalgo (n. 1), p. 25 y Pizarro Wilson (n. 1), p. 100.
}

${ }^{8}$ Cfr. Pizarro Wilson (n. 1), pp. 2-3. El autor afirma que las sentencias analizadas en su trabajo muestran una clara tendencia a fijar la compensación económica en una suma de dinero dividiendo su pago en cuotas reajustables, mensuales, sucesivas en el tiempo; y agrega que la solución de un solo pago constituye una excepción.

${ }^{9}$ Una sentencia de la Corte de Apelaciones de Antofagasta, dictada en la causa rol $\mathrm{N}^{\circ} 69-2006$, de 11 de abril de 2006, el tribunal acepta la posibilidad de que se verifique la aplicación de una renta o pensiones vitalicias. En ella se lee: “(...) de tal manera que, desde este punto de vista, las pensiones vitalicias o de alimentos pugnan con el divorcio y sólo deberá establecerse en casos extremos de cónyuges desvalidos que no tengan posibilidad de ejercer el derecho de alimentos en otras personas (...)". Otra sentencia de la Corte de Apelaciones de Santiago, dictada en la causa rol N 8082-2006, de 18 de octubre de 2007, rechazando la posibilidad de compensaciones económicas vitalicias o perpetuas, estimo improcedente la constitución de usufructo de carácter vitalicio y la manutención como carga en la ISAPRE de la demandante de compensación atendido que con la sentencia de divorcio se pierde la calidad de cónyuge. En la doctrina, la profesora Carmen Domínguez Hidalgo, se inclina por aceptar la posibilidad de fijar una compensación económica como renta vitalicia. Domínguez Hidalgo (n. 1), p. 26. Siguiendo la misma línea, pero con referencia al acuerdo de compensación, Hernán Corral Talciani afirma: "En virtud de esta libertad (la de fijar la cuantía y forma de pago de la compensación económica), y aunque la compensación por sí misma no tenga una naturaleza alimenticia, no vemos obstáculo para que se pacte una pensión de alimentos de origen voluntario o una renta vitalicia”. CORRAL TALCIANi (n. 4), p. 35. En contra y acertadamente, Pizarro Wilson (n. 1), p. 7. Comentando las sentencias citadas en esta nota, el autor estima que el fijar una compensación indefinida constituye una renuncia a determinar una cuantía en una suma de dinero fija, ya que la incertidumbre de la llegada de la muerte del cónyuge impide su valoración. En mi opinión, atendida la finalidad 
Desde este ángulo, si las partes acuerdan o el juez decreta el pago de la compensación en cuotas, que como se ha explicado es la regla, resulta indispensable asegurar al acreedor la satisfacción de su crédito y de paso el respeto del principio de protección al cónyuge más débil.

Entonces, la fijación de las modalidades de pago de la prestación reconocen dos límites: el primero refiere a la finalidad perseguida por el legislador en esta materia, en la especie, poner de una sola vez, o en el corto o mediano plazo, fin al conflicto entre los cónyuges en lo patrimonial; y, el segundo, que concierne a la protección del cónyuge beneficiario, que debe quedar a cubierto ante un posible y eventual incumplimiento del cónyuge deudor.

Partiendo de la constatación de una incorrecta aplicación de las normas sobre forma de saldar el beneficio, el presente trabajo tiene por objetivo descifrar cómo la ley protege el derecho a la compensación económica a través de las citadas normas, demostrando que es el juez de familia quien debe otorgar tal protección, asegurando al cónyuge acreedor la satisfacción de su crédito. Con este fin, primeramente, me ocuparé de examinar a la compensación económica como derecho de origen legal, del que nace una acción personal para conseguir su cumplimiento y, seguidamente, desvelaré el régimen sobre la forma de pago de la obligación correlativa. Finalmente, me preguntaré sobre las facultades del juez al ser requerido para aprobar un acuerdo de prestación compensatoria. El trabajo termina con unas breves conclusiones.

\section{EL DERECHO \\ A LA COMPENSACIÓN ECONÓMICA}

Como se sabe, constituye un derecho establecido a favor del cónyuge que por dedicarse durante matrimonio a la familia no desarrolló una actividad remunerada o lo hizo en una menor medida de que la que quería y podía, y que el divorcio o la nulidad le causará un menoscabo económico. Correlativamente, es una obligación legal que pesa sobre el otro cónyuge -aquél que sí desarrollo una actividad remunerada o lo hizo en

del legislador y el carácter limitado de la autonomía privada en materia matrimonial y de familia en general, los cónyuges no pueden pactar como forma de pago de la compensación económica una pensión o renta vitalicia. Tal pacto debiera ser rechazado por el tribunal cuando le sea sometido a su aprobación por contrariar el régimen indisponible sobre la entrega de la compensación, al que se somete no sólo el juez sino, también, las partes. Lo que no puede hacer el sentenciador no le está permitido a las partes. Distinta es la situación que podría presentarse si es que el juez o las partes, una vez fijada su cuantía, destinaran el beneficio al pago del precio de una renta vitalicia. 
mayor medida que el otro- quien debe ejecutar una prestación de dar, en beneficio del titular del derecho ${ }^{10}$.

$\mathrm{El}$ artículo 60 de la LMC, al prever sobre los efectos de la sentencia firme de divorcio, ordena la extinción de todos los derechos de carácter patrimonial que emanan del matrimonio, como los alimentos y los derechos sucesorios, precisando que este efecto debe entenderse sin perjuicio de lo prevenido en el párrafo 1 del capítulo siguiente, que trata sobre la compensación económica, quiere decir, el derecho a ella. A su turno, el artículo 61 la califica como un derecho del cónyuge que no trabajó durante el matrimonio, por dedicarse tanto al cuidado de los hijos como a las labores del hogar común y que a causa del divorcio o nulidad sufre un menoscabo económico ${ }^{11}$. Entonces, este beneficio se sitúa entre los efectos patrimoniales del matrimonio, con la particularidad que éste se despliega sólo si el matrimonio termina por divorcio o nulidad, siempre que concurra el supuesto de hecho que prevé la ley.

Este derecho -el de la compensación económica- y su obligación correlativa tienen su origen en la ley, sin que sea de interés si ella es establecida por el juez o por los cónyuges mediante una convención. En ambos casos el derecho nace por la sola concurrencia del supuesto legal; la sentencia o la convención simplemente así lo declaran y reconocen. La convención hace las veces de la sentencia judicial ${ }^{12}$. En la compensación económica la fuente del derecho y obligación correlativa siempre es la ley ${ }^{13}$.

${ }^{10}$ Sobre la compensación como derecho de origen legal, véase Javier BARRIENTOS Grandon, "La compensación económica como 'derecho' de uno de los cónyuges y 'obligación' correlativa del otro. De sus caracteres”, en Revista Chilena de Derecho Privado, No 9, Santiago, diciembre 2007 y Álvaro Vidal Olivares, "La noción de menoscabo en la compensación económica por ruptura matrimonial", en Revista de Derecho, vol. XxxI, No 2, Valparaíso, 2008, pp. 294-297.

${ }^{11}$ El artículo 64 también la califica como un derecho.

${ }^{12}$ Ocurre lo mismo con los alimentos debidos por ley, la circunstancia de que exista acuerdo entre el alimentante y alimentario, no permite concluir que la obligación de dar alimentos ya no tiene su fuente en la ley, sino que en una convención. Los alimentos siguen siendo debidos por ley.

${ }^{13}$ Con una opinión diversa: Barrientos Grandon (n. 10), p. 15. Para el autor el derecho personal o crédito de compensación y su obligación correlativa puede tener su fuente o causa en la ley, es decir, en una declaración de voluntad soberana (artículos 1, 578, 1437, 2284 del $C C$ ), pues así se prevé en el artículo 61 de la LMC al precisarse los supuestos de hecho necesarios para que se genere la causa legal del derecho de compensación económica al constituir a uno de los cónyuges en acreedor del otro. También puede existir un derecho personal o crédito de prestación compensatoria y su obligación correlativa causada en el hecho voluntario de los cónyuges, concretamente en una convención suya, pues así se prevé en el artículo 63 de la LMC complementado por el artículo 64, haciéndose expresa referencia al primero de ellos, a que este derecho puede ser convenido por los cónyuges. 
Por lo demás, así fluye de los artículos 63 y 64 de la LMC, conforme a los cuales los cónyuges pueden convenir la prestación, su procedencia, monto y forma de pago; y sólo a falta de acuerdo, tal tarea corresponda tal juez de familia.

En la doctrina, Javier Barrientos Grandon asevera que la compensación económica es un derecho personal o crédito que tiene unos caracteres propios y que la LMC le asigna los siguientes:

a) el de un derecho matrimonial, entendido así en la medida que su titularidad y ejercicio se funda en la existencia del matrimonio (artículo 60 de la LMC) y

b) el de un derecho de carácter patrimonial dentro de los citados derechos matrimoniales (art. 60 de la LMC).

El autor añade que debe hacerse un esfuerzo dogmático para analizarla como un derecho de naturaleza familiar, al no ser procedente aplicar las categorías propias del libro IV del Código $\mathrm{Civil}^{4}$. Continúa explicando que de la naturaleza familiar de este derecho fluye que se rige exclusivamente por las normas que constituyen su régimen legal, no siendo permitido acudir a las reglas del Derecho Común para suplir las lagunas que se detecten, sino que a la propia LMC y los principios en que ella se inspira, representando un papel esencial el principio de la protección del cónyuge más débil de su artículo 3.

Del derecho o crédito en que ella se traduce nace una acción personal que confiere a su titular la facultad de exigir a otro -el cónyuge deudor- el cumplimiento de su obligación correlativa contraída por la sola disposición de la ley. La acción personal que nace del derecho o crédito tiene por finalidad el cumplimiento o ejecución de la obligación y no el reconocimiento del derecho y fijación de su cuantía ${ }^{15}$. Esta última es una acción declarativa y se halla sometida exclusivamente a las normas de la LMC, que fijan las condiciones para que nazca el derecho a la compensación, la forma de fijarlo (judicial y convencional); el momento para pedirlo judicialmente, los criterios para su cuantificación y la forma de cumplimiento. La acción personal, en cambio, persigue la extinción de la obligación, ya reconocida convencional o judicialmente, que al carecer de un régimen especial se somete completamente al Derecho Común y nace del incumplimiento de la obligación, produciendo los efectos propios de las derechos y obligaciones de origen contractual. El cónyuge titular del derecho es un acreedor como cualquiera otro, sin que sea relevante la naturaleza familiar de su derecho.

${ }^{14}$ Barrientos Grandon (n. 10), pp. 12, 16-17.

${ }^{15}$ Esta distinción se recoge de Javier Barrientos Grandon, quien, a su vez, hace mención expresa a la acción personal para exigir el cobro de la compensación económica convenida entre los cónyuges, diferenciándola de la acción por la cual el acreedor persigue el cumplimiento de la sentencia judicial. Véase $i b i d$ 
Para los efectos de este trabajo la acción que interesa es la personal de cobro, la que de no mediar por parte del tribunal la observancia del marco legal sobre la forma de pago de la asignación puede dejar un muy mal pie al acreedor afectado por el incumplimiento, al punto de quedar privado definitivamente de la satisfacción de su crédito. Es el juez quien debe fortalecer esta acción personal, asegurando, de este modo, que el acreedor obtendrá el pago de la obligación pese al incumplimiento.

\section{LA PROTECCIÓN DEL DERECHO A COMPENSACIÓN ECONÓMICA. SU FORMA DE PAGO}

Si hay acuerdo en torno a que la compensación económica constituye un derecho de origen legal y carácter patrimonial, entonces su titular tiene un crédito en contra del cónyuge deudor, quien deberá satisfacerlo según la modalidad de solución fijada por el juez o las mismas partes.

Como se ha anticipado, este crédito no goza de ninguna clase de preferencia. El beneficiario está en la misma situación que cualquier otro acreedor del cónyuge deudor. La ley no considera a este crédito entre los privilegiados, en circunstancias que podría haberle incorporado entre los créditos de primera clase, como lo hace con la indemnización laboral (artículo 2472, $\mathrm{N}^{\mathrm{o}} 8$, del $C$ C); o los de cuarta clase, como ocurre con los créditos de la mujer en contra de su marido, nacidos de la administración de sus bienes propios o de los bienes gananciales (artículo 2481, $\mathrm{N}^{\circ} 3$, del $C C$ ). El crédito de compensación es quirografario y el beneficiario, en caso de incumplimiento, concurrirá en un pie de igualdad con los otros acreedores de la misma clase, no así con aquellos titulares de un crédito privilegiado o hipotecario. Así, el trabajador a quien el cónyuge deudor debe una indemnización de naturaleza laboral o con una causa en el contrato de trabajo o su terminación, al ser titular del crédito de primera clase, prefiere al acreedor de la compensación económica. El beneficiario afectado por el incumplimiento de la obligación de compensación estaría situado en el mismo lugar que el banco con el que el deudor contrató un préstamo de consumo, salvo que este acreedor tenga una hipoteca o una prenda puesto que preferirá al acreedor de compensación.

Lo dicho explica la regulación contenida en la LMC en lo que refiere al cumplimiento y sus modalidades. La ley fija específicamente las modalidades, demarcando la facultad del juez para determinar su forma de verificación. De lo que se trata es que ésta proteja al acreedor en términos de contar con seguridades para la plena satisfacción de su crédito. A continuación, describiré en el régimen a que se somete el pago de la compensación y, enseguida, me referiré particularmente al desembolso 
en cuotas y a las cuestiones no previstas por el legislador que pudieren afectar la satisfacción del derecho a este beneficio.

\section{Forma de pago de la obligación de compensación económica en la LMC}

En el Derecho chileno, al igual que en el Derecho francés ${ }^{16}$, la compensación es una prestación única -una suma alzada-y que tiene por objetivo corregir la carencia que provoca el divorcio o nulidad y el empeoramiento económico que se produciría de no mediar la prestación. Tal como se anticipó en la introducción de este trabajo, la finalidad perseguida por el legislador es que el conflicto patrimonial entre los cónyuges se solucione de una sola vez o a lo sumo dentro de un corto plazo, apareciendo teóricamente como regla en esta materia el pago en dinero de contado y como excepción cualesquier otra de las modalidades previstas por la LMC y leyes especiales. Teóricamente porque, como también se observó, en la jurisprudencia la regla está representada por la solución en cuotas y la excepción por el pago de contado.

Los artículos 65 y 66 de la LMC fijan el marco legal sobre la forma de cumplimiento de la compensación y representa un mínimo de protección indisponible para el juez y las partes y que, como tal, deja abierta la posibilidad para que el juez autorice una forma diversa siempre que, conforme el artículo 3 de la LMC, igualmente quede a salvo el interés del cónyuge acreedor y no se desatienda la finalidad tantas veces aludida. Cualquier otra modalidad de ejecución distinta a las previstas por el legislador, deberá fundarse por el sentenciador, en particular en cuanto a su adecuación con la finalidad que persigue el legislador con la compensación económica y con la protección del interés del beneficiario.

De acuerdo con la primera disposición, la obligación puede pagarse en dinero o en especies; o mediante la constitución de un derecho real de usufructo, uso o habitación sobre un inmueble de propiedad del cónyuge

${ }^{16}$ A diferencia de lo que ocurre en el Derecho Civil español, dado que la actual compensación económica por regla general se concibe como una prestación periódica temporal o de tiempo indefinido; o una prestación única, según se establezca en el acuerdo regulador o en la sentencia. Véase María Luisa Moreno-Torres Herrera, "La pensión compensatoria", en Julio GAVIdiA SÁNCHEZ (coord.), La reforma del matrimonio (Leyes 13 y 15/2005), Madrid, Marcial Pons, 2007, pp. 181-182. El actual párrafo primero de artículo 97 del Código Civil español prescribe: "El cónyuge al que la separación o el divorcio produzca un desequilibrio económico en relación con la posición del otro, que implique un empeoramiento en su situación anterior en el matrimonio, tendrá derecho a una compensación que podrá consistir en una pensión temporal o por tiempo indefinido, o en una prestación única, según se determine en el convenio regulador o en la sentencia”. 
deudor. Concretamente, el juez puede fijar cualquiera de las siguientes modalidades de pago:

a) Entrega al cónyuge beneficiario de una suma de dinero, especies o acciones. Ésta es la regla que debiera gobernar el pago de las prestaciones económicas, es decir, la entrega de un monto único o, a lo sumo, la dación en pago de especies -muebles o inmuebles-o acciones de propiedad del deudor. Ésta es la solución ideal y que verdaderamente permite cumplir con la finalidad del legislador, de poner término de una sola vez al conflicto entre los cónyuges que se divorcian, limitando su relación en lo patrimonial a lo que refiere a los hijos comunes ${ }^{17}$. Sin embargo, ya se he anticipado que en la práctica, atendida la realidad económica de nuestro país, esta modalidad es más bien excepcional ${ }^{18}$.

El mismo precepto considera lo que hoy en la práctica judicial constituye la regla, el cumplimiento en cuotas, expresadas en unidades reajustables, debiendo el juez fijar seguridades para su pago.

La expresión "seguridades para el pago" que emplea el legislador, comprende no sólo las garantías y cauciones -constitutivas de mecanismos de protección del derecho de crédito al ensanchar el derecho de garantía general del acreedor- sino todos aquellos mecanismos o medidas que den certeza al acreedor acerca del pago, evitando o previniendo, o el incumplimiento, o la insatisfacción definitiva del crédito. Así, constituyen seguridades para el pago, todas las cauciones -personales o reales-; cualquiera modalidad de las garantías bancarias, los seguros de responsabilidad, las cláusulas de aceleración ${ }^{19}$, una prohibición de enajenar, la retención judicial

${ }^{17}$ Como afirma Jean Carbonnier hay razones de distinto tipo que aconsejan concentrar los efectos pecuniarios de la ruptura alrededor del juicio de divorcio: no es bueno sicológicamente, afirma el autor, que se prolongue entre los esposos la relación acreedordeudor, aparte del hecho de que la disposición a pagar es mayor en los primeros tiempos, Jean Carbonnier, Droit Civil, 21 edition refondue, Paris, PUF, 2002, tome 2, p. 609.

${ }^{18}$ La sentencia de la Corte de Apelaciones de Santiago recaída en la causa rol $\mathrm{N}^{\circ}$ 8115-2005, de 15 de marzo de 2006, condena al demandado al pago de la suma única de \$20.000.000, que deberá entregarse dentro de los treinta días de ejecutoriada la sentencia. En otra sentencia de la misma Corte de Apelaciones de Santiago recaída en la causa rol $\mathrm{N}^{\mathrm{o}} 6475-2006$, de 4 de octubre de 2007, se condena al demandado otorga la suma única de $\$ 50.000 .000$ exigible en una sola cuota, mediante depósito en la cuenta corriente de la cónyuge beneficiaria.

${ }^{19}$ Véase la sentencia de la Corte de Apelaciones de Rancagua recaída en el recurso rol $\mathrm{N}^{\mathrm{o}}$ 1731-2006, de 20 de junio de 2006, que condena al demandado a una compensación económica de 266.67 ingresos mínimos mensuales general, en su equivalente en pesos, moneda de curso legal, que debía consignarse, a elección del recurrido, de contado o 
o descuento de un porcentaje de remuneraciones por parte del empleador $^{20}$. Tan amplia es la noción de seguridades para el pago que pudiere entenderse incluida en ella la modalidad especial que prevé la ley $\mathrm{N}^{\circ} 20.255$ que contempla el traspaso de fondos de capitalización obligatoria hasta el límite del 50\% existente del cónyuge deudor, con independencia del régimen patrimonial del matrimonio. Sobre esta forma de pago, que se la puede mirar también como una seguridad, me referiré más abajo.

b) La constitución de derechos reales de usufructo, uso o habitación. Esta forma de ejecución no se condice mucho con la naturaleza jurídica de la compensación económica puesto que la aproxima más a la idea de los alimentos debidos por ley. Con ocasión de su constitución en la práctica podría producirse un tránsito desde un derecho real -usufructo, uso o habitación- constituido en cumplimiento de la obligación de dar alimentos o uno que recaiga sobre el inmueble declarado bien familiar, a la conservación de ese derecho real ahora a título de prestación compensatoria. Este tránsito no debe llevar a confundir la naturaleza jurídica de las instituciones en juego.

En el caso que el juez o las partes fijen esta forma, conviene considerar la necesidad de cuantificar previamente la compensación y posteriormente imputar el derecho real al monto resultante,

en ciento ochenta coutas, iguales, mensuales y sucesivas, el último día de cada mes, correspondiendo cada una de ellas en su equivalente en moneda de curso legal a 1.4815 ingresos mínimos mensuales general, importando el no pago de una de ellas, la exigibilidad total y de contado de lo ordenado..

${ }^{20}$ Para un concepto amplio de seguridades para el pago véase: sentencia de la Corte de Apelaciones de Temuco recaída en el recurso $\mathrm{N}^{\circ}$ 150-2006, de 31 de julio de 2006. El tribunal, junto con dividir la compensación en cuotas, fija una seguridad para el pago consistente en la retención de la cuota por parte del empleador del deudor. En la sentencia se lee: "Se declara: a) que se acoge dicha demanda, por lo que el demandado reconvencional, esto es, Juan Agustín Jara Arteaga, deberá pagar a la demandante reconvencional singularizada la suma de $\$ 5.000 .000$ (cinco millones de pesos) a título de compensación económica ocasionada por el divorcio; b) Que la expresa suma será pagada en cincuenta cuotas mensuales iguales, las que se pagarán mes a mes, antes del último día de cada mes; c) Que se oficiará al empleador del demandado reconvencional para que retenga la expresada cuota en cada liquidación de remuneraciones, procediendo a entregar directamente la respectiva suma a la cónyuge beneficiaria; d) Que las cuotas se reajustarán una vez al año, en el mes de diciembre de cada año, en la misma forma y proporción en que haya experimentado variación la unidad de fomento". También, la sentencia de la Corte de Apelaciones de Santiago recaída en recurso rol No 4784-2007. Declara que el demandado debía otorgar a la actora en la suma de veinticuatro millones ciento noventa y dos mil pagaderos en ciento veinte mensuales de 10,35 UF cada una mediante retención judicial directa de la jubilación del demandado. 
lo que necesariamente implica limitar su vigencia en el tiempo. La constitución de un derecho real vitalicio a favor del acreedor contradice la propia naturaleza y objeto de la institución ${ }^{21}$.

En la práctica, la constitución de un derecho real como forma de pago es más bien excepcional y comparto la opinión de que el juez debiera evitar decretar esta modalidad porque ella, incluso, con una vigencia delimitada en el tiempo, se opone a la finalidad perseguida por el legislador, dado que prolonga en el tiempo la relación en lo patrimonial entre los que fueron cónyuges, constituyendo o pudiendo constituir una fuente de conflictos. El propietario queda a la espera del vencimiento del plazo para recuperar la propiedad y así disponer de ella. El juez debiere preferir las otras formas de verificación, incluso, la dación del mismo bien en pago de la obligación ${ }^{22}$.

El legislador prevé una regla de protección de los intereses de los terceros acreedores, propia y característica de los efectos patrimoniales del matrimonio, similar a la del artículo 1723 del Código Civil. Según la disposición, la constitución de los derechos reales no perjudicará a los acreedores que el cónyuge propietario hubiere tenido a la fecha de su constitución, de manera que ellos igualmente podrán requerir la realización del inmueble como si el derecho real no se hubiere constituido y quien se lo adjudique lo adquirirá libre de todo gravamen. En síntesis, la constitución del derecho real es inoponible a estos terceros. Sin embargo, la disposición va más allá al declarar que el derecho real que se constituya como forma de pago de la compensación no aprovechará a los acreedores que el beneficiario tuviere en cualquier tiempo -antes o después de su constitución-. Quiere decir que el derecho real no ingresa a la garantía general de los acreedores del cónyuge favorecido. Esta última disposición resulta relevante para el derecho real de usufructo, empero inútil e innecesaria para el de uso o habitación, al ser inembargables según el artículo 1618 del Código Civil.

c) Si el cónyuge no tiene bienes suficientes, el artículo 66 prevé una modalidad de pago residual que autoriza al juez dividir el capital, objeto de la compensación, en tantas cuotas como fuere necesario, las que, al igual que las del artículo 65, numeral 1), deberán ser expresadas en alguna unidad reajustable. Y como siempre debe dotarse al acreedor de alguna seguridad, se asimila la cuota a los alimentos

${ }^{21}$ Así se recoge en Pizarro Wilson (n. 1), pp. 5-6.

${ }^{22}$ Ibid 
debidos por ley, para efectos de su cumplimiento, salvo que el deudor ofrezca otras garantías para su efectivo y oportuno pago, todo lo cual deberá declararse en la sentencia. La compensación económica conserva su naturaleza jurídica, ni siquiera en este caso constituye alimentos debidos por ley. La asimilación se hace para un solo efecto: el cumplimiento de las cuotas; y representa para el acreedor una seguridad para el pago, como cualquiera de las que el juez puede considerar según el artículo 65, numeral 1). Cabe consignar que en la discusión a que dio lugar el precepto se afirma que:

"Sin duda es una figura híbrida, pero que a veces la pureza jurídica debe ceder ante la necesidad social de la institución y por esa razón se sugiere asimilarla a los alimentos no sólo por la posibilidad de solicitar el arresto nocturno del infractor ante el incumplimiento, sino también por el procedimiento ejecutivo simplificado para su cobranza”.

Se reconoce que el arresto nocturno no tiene gran efecto para producir el pago, pero sí constituye un incentivo para el cumplimiento del que no se podría prescindir ${ }^{23}$.

d) Finalmente, hoy se debe considerar una nueva modalidad de pago, la prevista por el artículo 80 de la ley $\mathrm{N}^{\circ} 20.255$ del año 2008, consistente en el traspaso de fondos de capitalización obligatoria hasta el límite del 50\% existente en la cuenta del cónyuge deudor y que hubiere acumulado durante el matrimonio. El traspaso lo decreta el juez y se hace a la cuenta de capitalización individual del cónyuge acreedor o de no ser titular de una, a la que se abra al efecto. Como sostiene Carlos Pizarro Wilson, al comentar esta modalidad, ella queda sujeta a un doble límite, por una parte no puede exceder el $50 \%$ de los fondos disponibles en la cuenta obligatoria y, por otra, sólo deben considerarse para el cálculo los fondos que se hayan originado durante el matrimonio ${ }^{24}$. Se critica esta modalidad

23 "Informe de la Comisión de Constitución, Legislación, Justicia y Reglamento", en Boletín 1759-18.

${ }^{24}$ Para el autor esta modalidad de pago cubre las expectativas de jubilación del cónyuge demandante que por dedicarse tanto a las tareas del hogar como al cuidado de los hijos se vio imposibilitado de cotizar o lo hizo en menor medida. Esta modalidad, a juicio del profesor Pizarro Wilson, en la mayoría de los casos resultará irrelevante cuando los fondos sean escasos, dado que permitirá acceder a una pensión modesta o de subsistencia. Esta modalidad sólo tendrá un impacto real cuando el cónyuge deudor haya capitalizado sustantivamente, produciendo, eso si, como efecto negativo, su empobrecimiento, al privarle de una pensión importante. Pizarro Wilson (n. 1), pp. 9-10. 
introducida por la norma provisional porque ella la restringe a los afiliados al sistemas de fondos de pensiones, dejando afuera a todos aquellos trabajadores sujetos a otros sistemas provisionales administrados por el INP y, también, por la CAPREDENA, lo que indudablemente constituye una discriminación injustificada para los acreedores de compensación ${ }^{25}$.

Este sistema puede decretarlo el juez exclusivamente o como complemento o juntamente con cualquiera de las examinadas en este apartado y confirma que, si bien la compensación económica se fija en el pasado, en las circunstancias en que se desenvolvió la vida marital, la mirada preferentemente es hacia el futuro y que el beneficio corrige la carencia producida por el divorcio o nulidad con la finalidad de evitar un empeoramiento futuro del cónyuge acreedor. Y puede alcanzarse este objetivo si la prestación cubre sus expectativas de jubilación y le permita, llegada la edad, disfrutar de los fondos en forma de pensión, con independencia de su cuantía, como si efectivamente hubiere desarrollado una actividad remunerada en la medida que quería y podía.

\section{La división de la compensación económica en cuotas para los efectos de su pago}

Hoy el juez divide la compensación en cuotas expresadas generalmente en unidades reajustables ${ }^{26}$ sin decretar seguridad alguna para el $\operatorname{pago}^{27} \mathrm{y}$,

${ }^{25}$ Un estudio crítico de esta nueva modalidad de pago de la compensación en PIZARro Wilson, op. cit., pp. 8-10.

${ }^{26}$ En la jurisprudencia prevalece el criterio de aplicar sobre cada una de las cuotas en que se divide la compensación la variación del IPC, pudiendo encontrar otros casos en los que las cuotas se reducen a UF e, incluso, algunos en los que la cantidad se expresa en ingresos mínimos mensuales (Corte de Apelaciones de Antofagasta, 25 de septiembre de 2007, rol N ${ }^{\circ}$ 177-2007) o en un porcentaje de remuneraciones (Corte de Apelaciones de Valparaíso, 6 de septiembre de 2006, rol $N^{\circ}$ 107-2006). El profesor Pizarro Wilson denuncia una disparidad en la aplicación de mecanismos de reajustabilidad de las cuotas, sosteniendo que es deseable una mayor uniformidad para hacer más accesibles dichos criterios, siendo de la opinión que debiere privilegiar la unidad de fomento o la variación del IPC. Pizarro Wilson, op. cit., pp. 3-4.

${ }^{27}$ Así pueden citarse a modo de ejemplo, las siguientes sentencias que son una muestra de esta mala práctica: a) Sentencia de la Corte de Apelaciones de Rancagua recaída en el recurso rol $\mathrm{N}^{\circ} 444-2006$, de 20 de julio de 2006. En la sentencia se declara que la compensación económica queda fijada en la suma de diez millones de pesos, pagadera, a elección del deudor, o al contado, o en cien cuotas mensuales e iguales de $\$ 100.000$ (cien mil pesos) cada una, a partir de la fecha de ejecutoria de este fallo, sumas que se reajustaran semestralmente conforme a la variación que experimente el IPC en cada período. b) Sentencia de la Corte de Apelaciones de Concepción recaída 
lo que resulta más grave, sin someter estas cuotas al régimen excepcional del artículo 66, impidiendo que el acreedor aproveche de la protección que prevé la norma ${ }^{28}$.

Las consecuencias que se seguirán de esta práctica judicial si el deudor incumple son nefastas. El titular del crédito no gozará de ninguna seguridad, quedándole sólo demandar ejecutivamente el cumplimiento de la sentencia como cualquier otro acreedor quirografario y es previsible que el deudor no tendrá bienes suficientes en su patrimonio y, seguidamente, el crédito quedará sin satisfacción.

De la revisión de las sentencias judiciales sobre compensación económica no resulta fácil distinguir el supuesto del artículo 65 1) de aquél del artículo 66, sobre todo porque al fraccionar el total en cuotas ni se fijan

en recurso de apelación $\mathrm{N}^{\circ}$ 2090/2006, de fecha 29 de agosto de 2006. La sentencia fija la compensación económica en la suma de $\$ 12.000 .000$, que se pagará en ciento veinte cuotas mensuales, de $\$ 100.000$ cada una, suma esta última que reajustará semestralmente, de acuerdo con la variación del IPC. c) Sentencia de la Corte de Apelaciones de Temuco recaída en recurso rol $\mathrm{N}^{\circ} 1465 / 2006$, de 29 de septiembre de 2006. En ella se declara que se rebaja la suma a la que fue condenado a pagar el demandado reconvencional por concepto de compensación económica, a la cifra de $\$ 4.320 .000$, pagaderos en setenta y dos cuotas mensuales de \$60.000 cada una. d) Sentencia de la Corte de Apelaciones de 84 Concepción recaída en el recurso rol No 217-2006, de 2 de octubre de 2006. La sentencia revoca la sentencia de primera instancia declarando que don Jaime Parra Herrera deberá pagar a título de compensación económica a Elisa Montecinos Rodríguez, la suma de $\$ 4.800 .000$ en cuarenta y ocho cuotas mensuales iguales y sucesivas de $\$ 100.000$ cada una, con vencimiento los días 25 de cada mes desde la fecha que esta sentencia quede ejecutoriada. Y agrega que la cuota mensual se reajustará en la misma proporción que varíe el IPC desde el mes anterior al de su vencimiento y el mes en que efectivamente ésta se cumpla. e) Sentencia de la Corte de Apelaciones de Concepción recaída en el recurso rol No 4064-2006, de 7 de mayo de 2007, que condena al demandado reconvencional Humberto Fabián Rivera Vergara al pago de una compensación económica a favor de la demandante reconvencional doña Miriam Alicia Verdugo Pereira, de \$4.054.782, 6 (cuatro millones cincuenta y cuatro mil setecientos ochenta y dos pesos, seis centavos) equivalente a $220 \mathrm{UF}$, pagaderas, ejecutoriada que sea esta sentencia, en diecisiete cuotas de 12,94 UF, que efectuará mediante el depósito de las sumas ordenadas en la cuenta corriente del tribunal a quo en el BancoEstado.

En ninguna de estas sentencias el tribunal fija seguridades para el cumplimiento de la compensación económica en cuotas, contrariando el precepto del artículo 65 de la LMC. En una sentencia aislada el tribunal fija como seguridad para el pago una cláusula de aceleración. En efecto, la Corte de Apelaciones de Rancagua, en su sentencia de 20 de junio de 2006, recaída en la causa rol $\mathrm{N}^{\circ}$ 529-2006, declara que el no pago de una de las cuotas en que se divide la compensación hará exigible el total como de plazo vencido.

${ }^{28}$ No son pocos los casos en los que el propio demandante reconvencional, solicita al juez que, para el caso de división en cuotas de la compensación, sean consideradas alimentos conforme el artículo 66 de la LMC. No obstante, el tribunal efectúa la divisiónen cuotas y no hace declaración alguna en su resolución, quedando el acreedor desprovisto de toda clase de seguridad. 
seguridades para el pago, ni las cuotas se someten al régimen especial del citado artículo 66.

Esta práctica judicial y la falta de nitidez de los supuestos del artículo $65,1)$ y del artículo 66 , hace necesario descifrar cómo debiere operar la división en cuotas, ofreciendo una interpretación armónica de ambas disposiciones que respete la finalidad que persigue la institución en estudio $\mathrm{y}$, al mismo tiempo, ampare el interés del acreedor, que pudiere verse afectado por el posterior incumplimiento de una o más de las cuotas, lesionando el principio de la protección del cónyuge más débil.

De la lectura conjunta de las disposiciones citadas, aparece que la división representa un beneficio para el deudor que deberá invocar al contestar la demanda y que el juez concederá o no, dependiendo del importe de la compensación económica, las facultades económicas del demandado y, por sobre todo, de las garantías o seguridades que él mismo ofrezca al solicitar la división en cuotas ${ }^{29}$ o que el juez decrete de oficio por estimarlas suficientes. Ahora bien, si el deudor no tiene bienes suficientes para pagar la suma decretada, él solicitará la división en cuotas según el artículo 66 de la LMC. Esto es, que la asignación se divida en tantas cuotas como sea necesario, habida cuenta las facultades económicas del demandado. Si el juez accede a la solicitud del artículo 66, lo que debe expresarlo en la sentencia, las cuotas serán consideradas alimentos debidos por ley para efectos de su cumplimiento.

El legislador persigue facilitar el pago de una compensación procedente de acuerdo con los artículos 61 y 62 de la $\mathrm{LMC}^{30}$, pese a la insuficiencia de bienes del demandado para satisfacerla y, de paso, evitar una condena destinada a no cumplirse poniendo en peligro la satisfacción del crédito establecido por sentencia judicial. El artículo 66 permite acceder a una modalidad de pago excepcional, que se traduce en la división del total en un elevado número de cuotas y muy probablemente de poca monta, $\mathrm{y}$, al mismo tiempo, como contrapartida, instituye a favor del acreedor una seguridad especial para el pago: la de considerar a las cuotas como

${ }^{29}$ Considerando a la división en cuotas una especie de beneficio que la ley reconoce al deudor, se pronuncia la sentencia de la Corte de Apelaciones de Temuco recaída en el recurso $\mathrm{N}^{\circ}$ 150-2006, de 31 de julio de 2006. En ella se lee: "Que la compensación económica admite ser pagada en alguna de las formas que indica el artículo 65 de la ley número 19.947 y para tales efectos se declarará que el deudor gozará de plazo, con las seguridades que se indicarán".

${ }^{30} \mathrm{Y}$ se hace esta precisión dado que no debe confundirse la procedencia de la compensación y la fijación de su cuantía con su forma de pago una vez establecida. En el supuesto del artículo 66 el juez declara procedente el bebeficio por concurrir las condiciones previstas por la ley, en especial, el menoscabo que producirá el divorcio o nulidad matrimonial. Las insuficientes facultades económicas del deudor justifican la división en cuotas según el artículo 66 de la LMC. 
alimentos para efectos de su cumplimiento. La ley hace aplicable a cada cuota las normas especiales dadas para el cumplimiento de las pensiones alimenticias y permite que el acreedor pueda beneficiarse de las medidas que la ley reconoce al alimentario. La cuota queda sujeta a las disposiciones de la ley $\mathrm{N}^{\mathrm{O}} 14.908$, sobre Abandono de Familia y Pago de Pensiones Alimenticias, que prevén como medidas concretas para el aseguramiento del cumplimiento de la obligación de dar alimentos: el arresto nocturno ${ }^{31}$, la retención de la devolución del impuesto a la renta, la suspensión de la licencia de conducir, la solidaridad en el pago de aquellas personas que dificulten o imposibiliten el cumplimiento de la obligación y el mismo procedimiento ejecutivo simplificado para el cobro forzado de las pensiones impagas.

No es fácil distinguir el supuesto normal de la división en cuotas del artículo 65 de aquél excepcional del artículo 66, cuestión que no es irrelevante si se considera la especialidad del régimen de pago que prevé esta última disposición. Pareciera que la diferencia entre estas dos modalidades reside en tres aspectos: uno, su procedencia. En el primer caso el demandado se limita a solicitar la división en cuotas y ofrece seguridades para el pago, siendo discrecional para el juez conceder o no tal beneficio; en el segundo, en cambio, el demandado solicita la división en tantas cuotas como fuere necesario habida cuenta la insuficiencia de sus bienes para pagar la compensación según el artículo 65, numeral 1) y el juez dará lugar a la petición en la medida que verifique la mermada situación patrimonial del deudor; tercero, el número de cuotas. En el primero, el criterio debe ser restrictivo, la prestación debiera parcelarse en un reducido número de cuotas; en el segundo, el criterio es amplio, acreditada la insuficiencia de bienes, el juez está facultado para dividir el beneficio en tantas cuotas como sea necesario, permitiendo de esta manera la extinción de la deuda. En tercer término, las seguridades para el pago. En el caso del artículo 65, el juez concederá el beneficio de la división en cuotas en la medida que las seguridades ofrecidas se juzguen como suficientes; en el segundo, la ley fija la seguridad y ella consiste en asimilar la cuota a los alimentos debidos por ley, salvo que el deudor ofrezca una seguridad diversa, que el juez aceptará en la medida que sea suficiente.

También puede acontecer que el demandado se limite a solicitar la división de la compensación en cuotas sin ofrecer garantías o, bien, que

${ }^{31}$ En contra, Patricio Véliz Moller, Divorcio, nulidad y separación. Los caminos frente a la ruptura, Santiago, Ediciones Cerro Manquehue, 2004, pp. 64 y 65 . El autor sostiene que debe descartarse el arresto como medida de apremio frente al incumplimiento, ya que vulneraría lo dispuesto en el artículo $7^{\circ}, \mathrm{N}^{\mathrm{o}} 7$ de la Convención Americana sobre Derechos Humanos (Pacto de San José de Costa Rica). 
sugiera alguna que sea considerada insuficiente según el criterio del juez. En un supuesto como el descrito, se estima que el juez puede decretar de oficio una seguridad ${ }^{32}$ o, bien, decretar la división en cuotas conforme el artículo 66, aunque no se le hubiere solicitado, siempre y cuando alcance la convicción en orden a que el demandado carece de bienes suficientes para otorgar la compensación. En caso contrario -si no llega a tal convicción- deberá decretar el pago de contado o la dación en pago de especies o acciones, la constitución de un derecho real de acuerdo con el artículo 65 de la LMC o el traspaso de los fondos de capitalización obligatoria desde la cuenta de capitalización individual del deudor a la ya existente del acreedor o a la que se abra al efecto.

De lo expresado en este apartado se sigue lo siguiente:

i) La división en cuotas constituye un beneficio que la ley prevé a favor del deudor de la compensación económica.

ii) El juez concederá la división en la medida que el demandado así lo solicite en su contestación y ofrezca seguridades suficientes, o que acreditando que carece de bienes suficientes para pagarla, pida que la compensación económica se sujete a la norma excepcional del artículo 66 de la LMC.

iii) El juez está facultado para dividir la compensación económica en un número reducido de cuotas, salvo que sea aplicable el artículo 66 , en cuyo caso tiene la libertad para fraccionarla en tantas cuotas como fuere necesario, atendidas las facultades patrimoniales del deudor.

iv) Si el demandado solicita la división en cuotas sin ofrecer una seguridad para el pago y no invoca la norma del artículo 66 de la LMC y el juez igualmente tiene la facultad para dividir la compensación en cuotas decretando de oficio una seguridad o, bien, sometiendo el pago de la compensación al artículo 66 de la LMC, en la medida que alcance la convicción de que el deudor carece de bienes suficientes para satisfacerla mediante alguna de las modalidades del artículo $65^{33}$.

${ }^{32}$ Como la retención de un porcentaje de las remuneraciones o una cláusula de aceleración.

${ }^{33}$ Así se observa excepcionalmente en la sentencia de la Corte de Apelaciones de Punta Arenas, recaída en el recurso rol No 33/2007, de 14 de abril de 2007. En ella el sentenciador fija la compensación económica en cuotas y las somete al artículo 66 de la LMC. En la sentencia se lee: "Se hace lugar a la demanda reconvencional interpuesta en forma subsidiaria a fs. 14 por doña Erika Irene Müller Pasmiño en contra de don Zivko Juan Babic Bartulovic, sólo en cuanto se ordena al demandado pagar a la demandante, por concepto de compensación económica y bajo el apercibimiento del artículo 66 de la ley de Matrimonio Civil, la suma de dinero de cinco millones de pesos $(\$ 5.000 .000)$, en diez 
El deudor evitará la aplicación del régimen legal de los alimentos si ofrece una seguridad para el pago efectivo y oportuno de las referidas cuotas.

\section{Lagunas de la LMC en materia de forma de pago y protección del acreedor de la compensación económica}

El régimen legal de la compensación económica, en lo que refiere a su forma de pago, deja sin resolver algunas cuestiones relevantes para la adecuada protección del interés del cónyuge acreedor. Se detectan ciertas lagunas en la norma, supuestos que pueden presentarse en la práctica y que no tienen una solución legal, siendo necesaria su integración, la que deberá inspirarse en la naturaleza misma del derecho a este beneficio y en los principios rectores en la materia. Cuatro son las cuestiones no resueltas por el legislador.

\section{a) La primera}

Como se sabe, el artículo 65 de la LMC, en su numeral 1) prevé como forma de pago la dación de especies o acciones. Llama la atención que el legislador, a diferencia de lo que ocurre en materia de régimen de participación en los gananciales, no prevea la posibilidad de la evicción posterior de la especie o acciones dadas y menos que no dé una respuesta acerca de la suerte que correrá el derecho de compensación una vez producida la evicción. La cuestión es: revive el derecho o, bien, éste se extingue irrevocablemente con la dación en pago y el acreedor afectado debe hacer uso de las acciones derivadas de la obligación de garantía propia de las convenciones onerosas. En materia de participación en los gananciales, expresamente se prescribe que de producirse la evicción de la cosa dada en pago del crédito de participación, éste último renace (artículo 1792-22 del CC). Esta solución se aleja de la general en materia de dación en pago, que se induce de la norma de la fianza, según la cual aquélla extingue irrevocablemente la obligación principal y, consiguientemente, la accesoria, inclusive cuando sobrevenga la evicción de la cosa dada en pago (artículo 2382 del $C C)^{34}$.

cuotas mensuales de quinientos mil pesos $(\$ 500.000)$ cada una, correspondiendo pagar la primera el día 15 del primer mes siguiente a aquel en que se encuentre ejecutoriado este fallo, y las siguientes sucesivamente en igual fecha, depositándolas en una libreta de ahorro que la demandante abrirá en el alguna institución bancaria, para estos efectos”.

${ }^{34}$ Sobre el crédito de participación en los gananciales y su satisfacción por dación en pago, véase Álvaro VidAl OlIVAREs, "La participación en los gananciales. Estudio del régimen económico matrimonial y de su inserción en el sistema de regímenes económicos en el derecho de la familia chileno", en Revista de Derecho, vol. xxv, Valparaíso, 2004, pp. 465-466. 
Entonces, ¿qué solución debe darse para el caso de la compensación económica que se satisface con una cosa distinta al dinero y luego sobreviene su evicción? No cabe duda de que el Código no regula la dación en pago como modo de extinguir las obligaciones, el régimen aplicable se construye a partir de una interpretación de las normas sobre el pago y algunas especiales diseminadas en el libro IV, como lo es el citado artículo 2382. Por esta razón si se atiende a la naturaleza familiar del derecho a la compensación económica, el problema planteado debiere resolverse aplicando por extensión analógica el artículo 1792-22 del $C C$, que es norma protectora del interés del cónyuge acreedor y que resuelve sobre un derecho de la misma naturaleza: el de la participación en los gananciales. Por consiguiente, si la compensación se paga mediante dación y sobreviene la evicción de la especie objeto de ella, el crédito renace, a menos que el beneficiario hubiere tomado sobre sí el riesgo de la evicción, tal como lo prevé la disposición del artículo 1792-22 $2^{35}$.

Quiere decir que sobre el acreedor de la prestación compensatoria no pesa la carga de citar de evicción al deudor, sino que simplemente una vez producida la evicción, él tiene derecho a ejercitar las acciones que emanan de la obligación primitiva de compensación, la que renace como si no hubiera intervenido este medio de extinguir las obligaciones.

Como se trata de una laguna y que el juez debe integrar caso a caso, tratándose de una compensación económica convenida se sugiere incorporar una cláusula que contemple este supuesto y se extienda expresamente la solución que la ley da para el crédito de participación o, bien, que el beneficiario tome sobre sí el riesgo de la evicción de la cosa dada en pago. También cuando las prestaciones se piden judicialmente, conviene que el demandante, denunciando la laguna, solicite que para el evento que se decrete como modalidad la dación en pago, se prevea la posibilidad de evicción haciendo aplicable por extensión analógica el precepto del artículo 1792-22.

${ }^{35}$ En la doctrina se discute si el acreedor que recibe la cosa en pago -que celebró esta convención cuyo efecto es la extinción de la obligación- tiene o no las acciones emanadas de la obligación de garantía envuelta en todos los actos a título oneroso; y si ésta se acumula o no con la acción primitiva emanada de la obligación en que incide la dación en pago. No cabe duda que si ésta extingue la obligación, mal podría afirmarse que si sobrevenga la evicción el acreedor que reciba la especie en pago puede ejercitar las acciones emanadas de la obligación primitiva. Lo único que procedería sería reconocer al acreedor la acción de saneamiento de evicción con su doble objeto y si en definitiva ella se produce, el deudor que la dio quedará obligado al saneamiento. Véase Hernán Barrios Caro y Gabriel Valls Saintis, Teoría general de la dación en pago. Estudio de doctrina y legislación, Santiago, Editorial Jurídica de Chile, 1961, pp. 88 -90. 
b) La segunda

Situación de los acreedores del cónyuge deudor de compensación que la paga mediante la constitución de un derecho real. La pregunta que surge es, ċla norma protectora de los terceros acreedores que recoge el artículo 65 de la LMC se aplica igualmente a los casos de compensación convenida y de necesaria aprobación judicial? Puede ser discutible la aplicación analógica de la norma, pero creo que recurriendo a los principios generales del Derecho se arriba a una misma solución. La cuestión se resuelve en virtud de los principios de la seguridad jurídica y protección de la apariencia, que privilegian a los acreedores por las actuaciones voluntarias posteriores de su deudor y que puedan perjudicar su derecho. Como afirma un autor, el principio de la seguridad jurídica se traduce en que:

"el tercero podrá actuar confiando en que no le han de perjudicar los actos llevados a cabo por otras personas y que sean desconocidos o posteriores respecto al momento en que ese tercero adquiere sus derechos" ${ }^{\prime 6}$.

La seguridad jurídica permite fundamentar la inoponibilidad del derecho real respecto de los acreedores anteriores del deudor que lo constitu90 ye.

De esta forma, si la constitución del derecho real está contenida en el acuerdo compensatorio, ella no perjudicará a los acreedores anteriores del deudor, siendo inoponible el derecho real. A esta inoponibilidad se ha llegado por vía judicial en materia de hipoteca cuando el constituyente posteriormente grava el inmueble con un derecho real de usufructo, que es declarado inoponible al acreedor hipotecario y, aunque la actuación posterior no sea voluntaria, en materia de bienes familiares pese a la falta de disposición sobre el particular, también se ha fallado a favor de la inoponibilidad de la declaración provisoria de bien familiar respecto del acreedor anterior del cónyuge propietario ${ }^{37}$.

${ }^{36}$ Luis Felipe RAGEL, Protección del tercero frente a la actuación jurídica ajena: la inoponibilidad, Valencia, Editorial Tirant Lo Blanch, 1994, p. 97.

37 "Que conforme a lo dispuesto por el artículo 142 del Código Civil, la declaración de bien familiar impide la enajenación o gravamen del inmueble objeto de tal declaración, y la promesa de dichos actos relativa a ese inmueble, efectuada voluntariamente por uno de los cónyuges, prohibición que surte sus efectos desde que se practica su inscripción, provisoriamente en el Conservador de Bienes Raíces competente, una vez presentada la demanda que persigue dicha declaración de bien familiar". Sentencia Corte de Apelaciones de Santiago, 11 de enero de 1999. Gaceta Jurídica, No 223, pp. 109. 


\section{c) La tercera}

Muy vinculada con las dos cuestiones anteriores, cabe preguntarse, ¿cuál es el efecto que produce en el crédito de compensación -que se satisface mediante la constitución de un derecho real- la realización del inmueble gravado con usufructo, uso o habitación? La compensación se paga mediante la constitución del derecho real, dándose por extinguida irrevocablemente. Pero el problema no es menor desde la perspectiva del acreedor a quien se le cumple bajo esta modalidad; puesto que a él se le privará del usufructo o el uso o habitación y, estrictamente, su derecho quedaría sin satisfacción. Entonces, ¿̇a quién pertenece el riesgo de la posterior realización del inmueble?, ¿̇al acreedor de la compensación o a su deudor? A mi juicio, el riesgo no puede pertenecer al acreedor, sino que al deudor de compensación que paga bajo esta modalidad, pues es él quien tiene acreedores anteriores y el ejercicio de sus créditos depende exclusivamente del pago que efectúe, de su actuación voluntaria. En otras palabras, el riesgo debe pertenecer al deudor puesto que la realización del inmueble gravado por los acreedores anteriores depende exclusivamente del hecho voluntario: la extinción de sus obligaciones preexistentes a la constitución del derecho real. Por ende, la solución debe ser similar a la propuesta para la evicción posterior de la especie dada en pago. El crédito renacería y el cónyuge acreedor podría intentar cobrarlo, como cualquier acreedor afectado por un incumplimiento. La norma aplicable por extensión analógica sería la del artículo 1792-22.

De todos modos, lo recomendable para precaver la posible falta de protección del crédito -ante la ausencia de regulación- es que las partes se anticipen a esta contingencia en la propia demanda o acuerdo y los efectos que producirá para el caso de su realización. Así, por ejemplo, el demandante puede solicitar esta modalidad de pago haciendo reserva de su derecho en caso de que la cosa gravada con el derecho real sea objeto de realización por los acreedores del cónyuge deudor.

\section{d) La cuarta}

¿Puede modificarse la compensación económica y su forma de pago por alteración de las circunstancias? La respuesta es negativa y lo es atendida la naturaleza jurídica de esta institución y su objeto. Una vez fijado su monto o su forma de pago, no puede modificarse -ni aumentarse, ni reducirse- aunque se alteren las circunstancias consideradas al momento de apreciar su procedencia y cuantía según lo prescrito por el artículo 62 de la LMC. La Comisión de Constitución, Legislación, Justicia y Reglamento del Senado 
"rechazó la posibilidad de que el deudor solicite el cese del pago del saldo insoluto, o su reducción, por la variación de su condición económica o de la del acreedor, o por el hecho de que su ex cónyuge se case nuevamente o conviva con otra persona".

Y el senador Rafael Moreno creyó injusto que el cambio de condiciones habilite para solicitar que se modifique el monto ya determinado, por cuanto éste responde a la situación coetánea al divorcio o a la declaración de nulidad, no a lo que ocurra posteriormente, lo que se advierte con claridad si se atiende al supuesto que el deudor hubiese pagado de contado, al que no se le reconocería derecho a devolución alguna ${ }^{38}$.

La compensación económica es inmutable a pesar de que se haya acordado o resuelto su pago en cuotas de acuerdo con el artículo $65 \mathrm{~N}^{\circ}$ 1 de la LMC y éstas se hallen pendientes ${ }^{39}$.

No obstante, cabe preguntarse qué ocurre cuando el juez somete el beneficio al régimen excepcional del artículo 66 de la LMC. Lo planteo dado que es perfectamente admisible sostener que la asimilación de las cuotas a los alimentos para efectos del cumplimiento no refiera exclusivamente al incumplimiento, sino, también, a su cumplimiento. Una lectura amplia del precepto permitiría fundar una solicitud de modificación de la forma de pago en caso de alteración de las circunstancias económicas del deudor, manteniéndose intacta la cuantía de la compensación. Quiere decir que si la prestación fue dividida en cien cuotas mensuales y sucesivas de 10 UF y la situación económica del deudor varía en términos que mejore o se empeore, el acreedor o el deudor podrán solicitar una modificación del número de cuotas y de su importe. Así, en el caso de que mejore la condición financiera del deudor, el acreedor podrá solicitar una reducción de las cuotas y aumento de su importe. La sentencia de compensación en este caso, el del artículo 66, produciría cosa juzgada formal en lo que concierne a la forma de pago. Sin duda, se trata de una lectura del precepto y un análisis con mayor detenimiento excede el objeto del presente trabajo, simplemente me limito a dejar planteada esta posible

38 "Informe de la Comisión... (n. 23), p. 171.

${ }^{39}$ Pronunciándose en contra de la inmutabilidad de la compensación económica: Susan Turner, "Las prestaciones económicas entre los cónyuges divorciados en la nueva Ley de Matrimonio Civil”, en Revista de Derecho, No 16, Valdivia, 2004, pp. 100-101. La profesora Turner critica el que la ley no contemple vías para solicitar la reducción o extinción de la compensación económica porque la parte deudora podría quedar vinculada económicamente durante años con quien la ley declaró ya no ser su cónyuge, sin consideración alguna de las variaciones que pueda sufrir su capacidad económica o la situación patrimonial de la parte acreedora. Y estima que ello constituye un desincentivo al trabajo tanto del cónyuge beneficiario como del deudor. 
interpretación amplia de la asimilación de la cuota a los alimentos para efectos de su cumplimiento.

\section{ACUERDO DE COMPENSACIÓN \\ Y PAPEL DEL JUEZ DE FAMILIA}

Como se sabe el nuevo Derecho Matrimonial reconoce un amplio margen a la autonomía de la voluntad de los cónyuges en situación de crisis o ruptura, apoyándose en el principio de la colaboración que implica privilegiar las soluciones convencionales sobre las regulaciones impuestas judicialmente; la mejor solución a las cuestiones de familia es aquélla que se dan las partes negociadamente.

La regulación judicial para estos asuntos queda reservada para aquellos casos en que las posibilidades de acuerdo han fracasado: no se logró conciliación (artículos 69 y 70 de la LMC). Ahí es el juez el que debe regular las cuestiones de resolución necesaria en juicios de familia (artículo 90 de la LMC), como la relación entre los cónyuges y sus hijos comunes, las cuestiones relativas a los regímenes matrimoniales, etcétera.

Sin embargo, el privilegiar a la autonomía privada sobre la imposición judicial no significa que el Estado descanse absolutamente en el entendimiento privado de los cónyuges, absteniéndose de intervenir. No, en las materias de Derecho de Familia hay ciertos intereses superiores que los acuerdos no pueden lesionar ${ }^{40}$. El Estado, a través del juez de familia, debe velar por la protección de tales intereses. El juez debe tutelar estos intereses al realizar un control de fondo de los acuerdos sometidos a su aprobación. Así, por ejemplo, los convenios reguladores de separación judicial y divorcio deben ser completos y suficientes (artículos 27 y 55 de la LMC); y el acuerdo de compensación económica requiere de la aprobación del juez (artículo 63 de la LMC).

El legislador prevé el acuerdo entre la pareja como la primera forma de establecer la procedencia, cuantía y forma de pago de la compensación económica. Sólo a falta de acuerdo, corresponde al tribunal fijar su procedencia, cuantía y forma de cumplimiento. El sentenciador la regula cuando así se le solicite en la demanda, en un escrito complementario o en la demanda reconvencional. Incluso, cuando no hay acuerdo previo y este derecho es demandado por uno de los cónyuges, es el propio juez el que debe promover un acuerdo entre las partes, sea en la conciliación, sea sometiendo la cuestión a procedimiento de mediación.

${ }^{40}$ Véase el artículo 3 de la LMC. 
Tal como se anticipó, el acuerdo de compensación requiere de aprobación judicial y cuando al tribunal se le requiere, debe necesariamente pronunciarse, aunque la ley no lo prescriba, sobre su suficiencia en los términos del propio artículo 55 de la LMC sobre convenio regulador de divorcio. Siendo así, surge la siguiente interrogante, ¿qué facultades tiene el juez frente a un acuerdo de compensación sometido a su aprobación? -la interrogante se justifica tanto para los casos en los que las partes someten al juez, para su aprobación exclusivamente, un acuerdo de compensación, como para aquéllos en que el acuerdo integra un convenio regulador de divorcio remedio-. La labor del sentenciador debe inspirarse en el principio de la protección al cónyuge más débil.

En otras palabras, ¿cuál es el alcance de la exigencia de aprobación del convenio, según el artículo 63 de la LMC? El juez debe limitarse a homologar el acuerdo fijándose exclusivamente en las cuestiones formales (escritura pública o avenimiento), sin atender el contenido del acuerdo; o verdaderamente debe aprobarlo, lo que implica un control de su contenido. Si se tiene en cuenta que la compensación económica es la manifestación más concreta del principio de protección del cónyuge más débil y que la regla en la LMC es la tutela judicial de los acuerdos cuando ellos inciden en intereses fundamentales que puedan verse perjudicados; y las

94 normas de control de los convenios reguladores en materia de separación judicial y divorcio, no cabe sino inclinarnos por la segunda alternativa. La aprobación que exige el artículo 63 supone un control del contenido del acuerdo, con la finalidad de determinar si sus términos dejan, o no, a salvo el interés que se busca resguardar con la compensación económica.

Habiendo resuelto esta interrogante, surgen otras dos: ¿con base a qué criterios el juez valora el contenido del acuerdo? y citiene el juez facultades para subsanar o modificar el acuerdo de compensación? La ley regula deficientemente la materia, limitándose a exigir la aprobación.

Resulta útil a estos efectos recurrir a las normas sobre los acuerdos reguladores de los artículos 27 y 55 de la LMC. Según estas disposiciones el convenio debe ser completo y suficiente. Será suficiente, en lo que ahora interesa, en cuanto aminore el menoscabo que pueda causar la ruptura y establezca relaciones equitativas hacia el futuro entre los cónyuges. Es claro que el legislador al repetir la disposición del artículo 27 en el artículo 55 , no cayó en la cuenta que los supuestos eran diversos.

En el primero, cuando se trata de la separación, en realidad podemos aceptar la redacción, siempre que entendamos que la expresión 'menoscabo' empleada no coincide con la del artículo 61 y siguientes, sino sencillamente alude al empeoramiento que puede implicar la vida futura separada, pese a la conservación del vínculo. De manera que el juez valorará la suficiencia del acuerdo apreciando el contenido de las 
relaciones patrimoniales establecidas entre los cónyuges, en materia de alimentos y regímenes matrimoniales.

En el segundo, la verdad es que sólo queda concluir que la suficiencia del acuerdo con relación a la pareja interesará cuando en el acuerdo se incluya o se regule la compensación económica y que aquí la suficiencia no viene dada porque el convenio aminore el menoscabo, sino que lo compense y establezca relaciones equitativas hacia el futuro. Quiere decir que la exigencia de la suficiencia respecto de la regulación de las relaciones entre los cónyuges sólo se justifica cuando el convenio regule la compensación.

El tribunal, entonces, al controlar la suficiencia del convenio regulador podría perfectamente modificarlo o subsanarlo. La ley no reconoce de forma expresa al esta facultad para el convenio regulador del divorcio, sin embargo, se llega a ella por aplicación analógica del artículo 31 de la LMC, establecido para el convenio de la separación judicial, que expresamente autoriza al juez para corregir y subsanar el acuerdo cuando no resulta suficiente. Si no se le reconoce esa facultad al tribunal de familia y el acuerdo no es completo o suficiente, junto con rechazar el acuerdo, debería no dar lugar a la demanda de divorcio, lo que sería impensable e indefendible en la actual configuración del Derecho Matrimonial. A cambio de la cláusula de dureza se otorgó al juez facultades exorbitantes para regular todas aquellas materias sometidas a su conocimiento velando por intereses que son superiores, descartándose la posibilidad de negar lugar a la demanda de divorcio por esta razón. Debe recordarse que en el divorcio de común acuerdo basta el cese de la convivencia por un año y la presentación de un convenio regulador; la complitud y suficiencia del acuerdo se valora después por el juez, quien podrá en la misma sentencia de divorcio completar, subsanar o modificar el acuerdo.

Pues bien, siguiendo la misma argumentación puede sostenerse que el juez de familia de valorar el contenido del acuerdo de compensación conforme el criterio de la suficiencia del artículo 55 de la LMC y en caso que no satisfaga esta exigencia, queda facultado para modificarlo o subsanarlo, sin que sea procedente su rechazo. Para este objetivo, el sentenciador podría decretar todas las medidas que estimara convenientes ${ }^{41}$.

${ }^{41}$ En este sentido, Domínguez Hidalgo (n. 4) p. 111."El juez tiene facultad de control del convenio en esta materia (al igual que las tiene en el de separación judicial y divorcio), desde que el acuerdo debe ser presentado a la aprobación judicial para que tenga fuerza vinculante para los cónyuges. Así lo dispone el artículo 63. En ejercicio de esta facultad y por aplicación de lo dispuesto en el art. 3 que lo manda a resolver las 'materias de familia reguladas por esta ley, cuidando proteger siempre el interés del cónyuge más débil' puede revisar íntegramente el convenio, en términos que si efectivamente quiere dejar mejor posicionado al cónyuge más débil, aumentando la prestación acordada, tendría fundamento para hacerlo. Todo ello, con mayor razón aún, si se tiene presente que éste es la figura 
Ahora bien, los jueces en esta labor deben ser muy cuidadosos, al ser evidente la tensión entre dos principios fundamentales del nuevo derecho del matrimonio, el de la autonomía privada y el de la protección al interés del cónyuge más débil, de forma que la modificación de los acuerdos de compensación procederá en casos extremos en los que evidentemente el acreedor de la compensación, se vea perjudicado gravemente o pueda verse perjudicado en el futuro. El juez fundamentará la modificación del acuerdo en la exigencia de la suficiencia del mismo y, precisamente, en el perjuicio o eventual perjuicio a los intereses del cónyuge más débil.

El magistrado al valorar el acuerdo y controlar su contenido debe considerar las disposiciones que integran el régimen legal de la compensación, en especial aquéllas fijan su forma de pago. Como se ha reiterado, éstas tienen un fin último, la protección del crédito y de su satisfacción. Ello queda de manifiesto con relación a la exigencia de transformar las cuotas en que se divide la compensación a unidades reajustables y a las facultades exorbitantes reconocidas al tribunal para disponer seguridades y calificarlas como suficientes o no. De modo que, si el acuerdo de compensación prevé un pago en cuotas pagaderas en pesos, el juez deberá modificarlo o corregirlo, aduciendo el principio de protección del cónyuge más débil, llevando las cuotas a unidades reajustables; o si la compensación se

96 fracciona sin prever seguridades, se dispondrá su otorgamiento, y si ello no es posible, se someterán las cuotas al régimen especial del artículo 66 de la $\mathrm{LMC}^{42}$. También podría reemplazar la forma de cumplimiento acordada, por otra prevista por el legislador como, por ejemplo, el pago en cuotas por la dación de un bien o la constitución de un derecho real, o el traspaso de fondos desde la cuenta de capitalización individual.

Lo que es norma para el juez también tiene que serlo para las partes. De otra forma, por privilegiar la autonomía privada como principio rector del nuevo Derecho Matrimonial, se pondría en peligro la observancia de otro principio, el de la protección del cónyuge más débil.

\section{Conclusiones}

1. Se observa de que a pesar que el legislador prevé un marco legal sobre la forma de pago de la compensación, la jurisprudencia

con la que en esta ley, por esencia, se le quiere proteger”. En esta misma dirección Corral TALCIANi (n. 4), p. 37.

${ }^{42}$ Las partes en el acuerdo podrían convenir en someter el pago de la compensación económica al artículo 66 de la LMC, produciéndose la asimilación de las cuotas a los alimentos desde la aprobación judicial, desde que en ese instante, y no antes, el acuerdo queda perfecto. 
al fijar la específica modalidad que ésta asumirá, desconoce tal marco legal, poniendo en serio riesgo la satisfacción del crédito de compensación económica y, de paso, la protección del interés del cónyuge más débil.

2. La compensación económica constituye un derecho y correlativamente una obligación de origen legales. Como derecho es de contenido patrimonial y tiene su fundamento último en el matrimonio. Y como tal, una vez establecido por sentencia judicial o acuerdo regulador, queda sometido al Derecho Común propio de las obligaciones.

3. El titular de este beneficio tiene un crédito desprovisto de toda clase de protección, un crédito quirografario que le deja en un pie de igualad con cualquier acreedor del cónyuge deudor e, incluso, en una situación de inferioridad si se trata de aquéllos anteriores al nacimiento del crédito de compensación, que serán preferidos por imperativo de la seguridad jurídica y la protección de la apariencia.

4. Dos son las ideas orientadoras de la actividad judicial en materia de modalidades de pago de la compensación. La primera es que el juez al fijar la forma en que éste se realiza debe intentar detener la finalidad perseguida por el legislador, en orden a solucionar prontamente el conflicto patrimonial entre las partes y evitar que tal forma de pago sea fuente de nuevos conflictos en el futuro. La segunda, es que el juez debe velar porque el cónyuge acreedor obtenga la satisfacción de su acreencia, incluso, cuando el deudor hubiere incumplido su obligación.

5. Quien debe dotar de protección al crédito de compensación es el juez, en él el legislador radicó esta tarea. El marco legal sobre la forma de pago de la compensación apunta hacia esa dirección. $\mathrm{Al}$ juez se le fijan ciertas restricciones de observancia necesaria.

6. Finalmente, las restricciones que la ley establece al sentenciador, en lo que concierne a la forma de pago, se extienden a los acuerdos entre los cónyuges, quienes están sujetos al mismo límite que el tribunal. De no respetarse estos límites, el juez previo a la aprobación del acuerdo, deberá subsanarlo

\section{BibliografíA}

BarRientos Grandon, Javier, “La compensación económica como ‘derecho’ de uno de los cónyuges y 'obligación' correlativa del otro. De sus caracteres”, en Revista Chilena de Derecho Privado, N 9, Santiago, diciembre 2007. 
Barrios Caro, Hernán y Gabriel Valls Saintis, Teoría general de la dación en pago. Estudio de doctrina y legislación, Santiago, Editorial Jurídica de Chile, 1961.

Carbonnier, Jean, Droit Civil, 21 edition refondue, Paris, PUF, 2002, tome 2.

Corral Talciani, Hernán, "La compensación económica en el Divorcio y la Nulidad Matrimonial", en Revista Chilena de Derecho, vol. 34, No 1, Santiago, 2007.

Domínguez Águila, Ramón, "La compensación económica en la nueva legislación de matrimonio civil", en Revista Actualidad Jurídica, No 15, Santiago, 2007.

Domínguez Hidalgo, Carmen, "La compensación económica en la nueva ley de matrimonio civil", charla efectuada el 13 de octubre de 2005, en Revista del Abogado, $\mathrm{N}^{\circ} 35$, serie Conferencias, Santiago, noviembre 2005.

Domínguez Hidalgo, Carmen, "El convenio regulador y la compensación económica: una visión de conjunto", en Anastasía Assimakópulos FigueroA y Hernán Corral Talciani (eds.), Matrimonio civil y divorcio. Análisis crítico y criterios para la aplicación de la Ley $N^{\circ}$ 19.947, de 2004, Santiago, Universidad de Los Andes, 2005.

GÓMez De la TORRE, Maricruz, Compensación económica en la nueva ley de matrimonio civil, Santiago, Colegio de Abogados de Chile, folleto, 2005.

"Informe de la Comisión de Constitución, Legislación, Justicia y Reglamento", en Boletín 1759-18.

Moreno-Torres Herrera, María Luisa, "La pensión compensatoria", en Julio Gaviria SÁnchez (coord.), La reforma del matrimonio (Leyes 13 y 15/2005), Madrid, Marcial Pons, 2007.

Pizarro Wilson, Carlos, "La compensación económica en la nueva Ley de Matrimonio Civil", en Revista de Chilena de Derecho Privado, No 3, Santiago, diciembre 2004.

PizArRo Wilson, Carlos, "El pago de la compensación económica en la jurisprudencia nacional", en Compensación económica por divorcio o nulidad, Santiago, Ediciones Universidad Diego Portales, Escuela de Derecho, Cuadernos de Análisis Jurídicos, 2009, vol. v.

RAgEL, Luis Felipe, Protección del tercero frente a la actuación jurídica ajena: la inoponibilidad, Valencia, Editorial Tirant Lo Blanch, 1994.

TuRner, Susan, "Las prestaciones económicas entre los cónyuges divorciados en la nueva Ley de Matrimonio Civil", en Revista de Derecho, ${ }^{\circ}$ 16, Valdivia, 2004.

VéLIZ Moller, Patricio, Divorcio, nulidady separación. Los caminos frente a la ruptura, Santiago, Ediciones Cerro Manquehue, 2004.

VIDAL Olivares, Álvaro, "La participación en los gananciales. Estudio del régimen económico matrimonial y de su inserción en el sistema de regímenes económicos en el derecho de la familia chileno", en Revista de Derecho, vol. xxv, Valparaíso, 2004. 
VIDAL OlIVARES, Álvaro, "La compensación por menoscabo económico en la Ley de Matrimonio Civil", en Álvaro Vidal Olivares (coord.), El nuevo Derecho chileno del Matrimonio (Ley $N^{\circ} 19.947$ de 2004), Santiago, Editorial Jurídica de Chile, 2006.

Vidal Olivares, Álvaro, "La noción de menoscabo en la compensación económica por ruptura matrimonial”, en Revista de Derecho, vol. Xxxi, $\mathrm{N}^{\circ} 2$, Valparaíso, 2008. 